\title{
Kesiapan Guru Matematika SMP di Kabupaten Purworejo dalam Implementasi Kurikulum 2013
}

\author{
Susanah Wati $^{1} *$, J. Jailani ${ }^{2}$ \\ ${ }^{1}$ SD IT Jabal Nur, Gamping Lor, Ambarketawang, Sleman, Yogyakarta 55294, Indonesia \\ 2 Jurusan Pendidikan Matematika, Universitas Negeri Yogyakarta, Jalan Colombo No. 1, Karangmalang, \\ Yogyakarta 55281, Indonesia. \\ * Korespondensi Penulis. Email: cindy_shinici@yahoo.com, Telp: +6281802750663 \\ Received: 15 ${ }^{\text {th }}$ June 2016; Revised: $20^{\text {th }}$ August 2016; Accepted: $1^{\text {st }}$ September 2016
}

\begin{abstract}
Abstrak
Penelitian ini bertujuan untuk mendeskripsikan kesiapan guru matematika SMP di Kabupaten Purworejo dalam implementasi Kurikulum 2013 ditinjau dari pengetahuan guru, sikap guru, dan kesiapan sarana prasarana. Penelitian ini adalah penelitian deskriptif menggunakan model Concurrent Embedded Strategy. Metode primer penelitian adalah metode kuantitatif yang dilakukan dengan survei, kemudian dilengkapi metode kualitatif yang dilakukan dengan observasi, wawancara dan dokumentasi. Populasi penelitian adalah seluruh guru matematika SMP kelas VII dan VIII di Kabupaten Purworejo. Sampel penelitian adalah 64 orang guru yang dipilih menggunakan teknik stratified random sampling. Analisis data deskriptif kuantitatif menggunakan 5 kriteria, yaitu Sangat Siap, Siap, Cukup, Kurang, dan Sangat Kurang. Analisis data kualitatif terdiri dari reduksi data, penyajian data dan penarikan kesimpulan. Hasil penelitian menunjukkan bahwa kesiapan guru matematika SMP di Kabupaten Purworejo dalam implementasi Kurikulum 2013 ditinjau dari: kesiapan pengetahuan guru masuk kategori sangat kurang, sikap guru masuk kategori cukup, dan kesiapan sarana prasarana masuk kategori siap.
\end{abstract}

Kata kunci: kesiapan guru, kesiapan pengetahuan, sikap guru, kesiapan sarana dan prasarana

\section{The Readiness of Junior High School Math Teachers in Purworejo for the Implementation of Curriculum 2013}

\begin{abstract}
This research aimed to describe the readiness of junior high school math teachers in Purworejo for the implementation of Curriculum 2013 in terms of the teachers' knowledge, the attitude of teachers, and the readiness of facilities and infrastructure. This study used mixed methods with models Concurrent Embedded Strategy. The study primary method was a quantitative research carried out by the survey, and equipped with qualitative methods conducted through observation, interviews and documentation. The population was all the 7th and 8th grade junior high school math teachers in Purworejo. The sample was 64 teachers established using the stratified random sampling technique. The quantitative descriptive data analysis used five criteria, namely: Very Ready, Ready, Fairly Ready, Poor, and Very Poor. While the analysis of qualitative data consists of data reduction, data display and conclusion.The results show that the readiness of junior high school math teacher in Purworejo for the implementation of Curriculum 2013 in terms of the readiness of the teacher's knowledge was in the very poor category, the attitude of teachers was in the fairly ready category, and the readiness of facilities and infrastructure was in the ready category.
\end{abstract}

Keywords: readiness of teachers, knowledge readiness, teachers' attitudes, readiness of facilities and infrastructure

How to Cite: Wati, S., \& Jailani, J. (2016). Kesiapan guru matematika SMP di Kabupaten Purworejo dalam implementasi kurikulum 2013. PYTHAGORAS: Jurnal Pendidikan Matematika, 11(1), 77-90. doi:http://dx.doi.org/10.21831/pg.v11i1.9675

Permalink/DOI: http://dx.doi.org/10.21831/pg.v11i1.9675 


\section{PENDAHULUAN}

Pembelajaran matematika pada setiap satuan pendidikan diharapkan mampu membekali peserta didik dengan ketrampilan dan kemampuan menghadapi berbagai permasalahan matematika maupun kehidupan sehari-hari. Kemampuan ini disebut sebagai daya matematis. Daya matematis ini tercantum pada tujuan umum pembelajaran matematika yang dirumuskan National Council of Teachers of Mathematics (2000, p.7) yaitu meliputi: (1) kemampuan pemecahan masalah (problem solving), (2) kemampuan penalaran (reasoning), (3) kemampuan berkomunikasi (communication), (4) kemampuan membuat koneksi (connection), dan (5) kemampuan representasi (representastion).

Berbagai kebijakan dilakukan pemerintah untuk dapat mencapai tujuan pembelajaran, salah satunya dengan perubahan dan pengembangan kurikulum. Kurikulum adalah seperangkat dokumen tentang rencana dan pengaturan yang berisi tujuan yang harus dicapai, isi materi dan bahan pelajaran yang harus dipelajari peserta didik serta strategi, cara dan evaluasi yang dikembangkan sebagai pedoman implementasi kegiatan pembelajaran untuk mencapai tujuan pendidikan tertentu di lembaga pendidikan (Olivia, 1992, p.9; Finch \& Crunkilton, 1999, p.11; Jackman, 2001, p.24; Howell \& Nolet, 2000, pp.35-36). Pengembangan Kurikulum 2013 merupakan langkah lanjutan pengembangan Kurikulum Berbasis Kompetensi (KBK) yang telah dirintis pada tahun 2004 dan Kurikulum Tingkat Satuan Pendidikan (KTSP) tahun 2006 yang mencakup kompetensi sikap, pengetahuan dan ketrampilan secara terpadu. Titik tekan pengembangan Kurikulum 2013 adalah penyempurnaan pola pikir, penguatan tata kelola kurikulum, pendalaman dan perluasan materi, penguatan proses pembelajaran, dan penyesuaian beban belajar.

Menurut Gultom (Kemdikbud, 2014: iii) pengembangan Kurikulum 2013 dilaksanakan atas dasar beberapa prinsip utama, yaitu: (1) standar kompetensi lulusan diturunkan dari kebutuhan, (2) standar isi diturunkan dari standar kompetensi lulusan melalui kompetensi inti yang bebas mata pelajaran, (3) semua mata pelajaran harus berkontribusi terhadap pembentukan sikap, keterampilan dan pengetahuan peserta didik, (4) mata pelajaran diikat oleh kompetensi yang ingin dicapai, (5) semua mata pelajaran diikat oleh kompetensi inti, dan (6) keselarasan kompetensi lulusan, isi, proses pembelajaran, dan penilaian.

Proses pembelajaran dengan mengimplementasikan Kurikulum 2013 telah dilaksanakan mulai tahun pelajaran 2013/2014 di kelas I dan IV untuk jenjang SD, kelas VII untuk jenjang SMP dan kelas $\mathrm{X}$ untuk jenjang SMA/SMK pada beberapa sekolah di 295 kabupaten/kota seluruh Indonesia yang ditunjuk pemerintah sebagai sekolah pilot-project (Surat Edaran Menteri Pendidikan dan Kebudayaan Nomor: 156928/MPK.A/KR/2013 tentang Implementasi Kurikulum 2013). Pada tahun pelajaran 2014/ 2015, implementasi Kurikulum 2013 dilaksanakan di semua sekolah di Indonesia pada kelas I, II, IV dan V untuk jenjang SD/MI, kelas VII dan VIII untuk jenjang SMP/MTs, dan kelas X, XI untuk jenjang SMA/MA/SMK/MAK. Hal ini berarti ada sekolah-sekolah yang pada tahun pelajaran 2013/2014 belum menerapkan Kurikulum 2013 pada kelas sebelumnya, tetapi pada tahun pelajaran 2014/2015 sudah harus mengikuti perubahan pada Kurikulum 2013. Akibatnya, siswa di sekolah yang sebelumnya menggunakan Kurikulum 2006 diharuskan menjalani matrikulasi pada awal semester gasal tahun pelajaran 2014/2015.

Berbagai kendala lain muncul di lapangan. Menurut hasil wawancara pada kegiatan pra survei didapatkan informasi bahwa buku pelajaran datang terlambat dan jumlah buku tersebut juga belum memenuhi kebutuhan satu buku untuk satu siswa sehingga berpengaruh dalam proses pembelajaran. Buku yang diterbitkan juga hanya buku kelas VII dan VIII, sedangkan buku siswa dan buku guru untuk kelas IX belum diterbitkan sehingga guru belum mendapatkan gambaran cakupan materi yang akan dipelajari di kelas IX, walaupun kompetensi dasar sudah dituangkan dalam Peraturan Menteri Pendidikan dan Kebudayaan. Hal tersebut dikarenakan tidak semua guru mencermati tentang Permendikbud pendukung Kurikulum2013.

Guru juga mendapatkan pelatihan atau diklat tentang Kurikulum 2013 yang diselenggarakan oleh pemerintah. Pelatihan untuk guru sasaran dilaksanakan selama lima hari berturutturut. Pelatihan ini diharapkan dapat membantu guru dalam implementasi Kurikulum 2013, tetapi pada kenyataannya di lapangan masih ada guru yang belum memahami sepenuhnya tentang Kurikulum 2013. Pengetahuan guru tentang Kurikulum 2013 masih kurang. Guru masih kesulitan dalam mengembangkan RPP, melakukan pembelajaran dengan pendekatan saintifik dan 
mengalami kendala dalam sistem penilaian. Menurut guru, isi dalam Kurikulum 2013 cukup bagus tetapi mereka menganggap Kurikulum 2013 nampak terburu-buru diterapkan dan kurang ada persiapan yang matang sehingga sebagian guru kurang memberikan respon positif terhadap implementasi Kurikulum 2013.

Munculnya berbagai kendala tersebut, membuat Menteri Pendidikan dan Kebudayaan menghentikan sementara pelaksanaan Kurikulum 2013 dan mengadakan revisi tentang Kurikulum 2013. Mendikbud mengeluarkan Permendikbud Nomor 160 Tahun 2014 tentang Pemberlakuan Kurikulum Tahun 2006 dan Kurikulum 2013 yang dilanjutkan dengan mengeluarkan Surat Edaran Menteri Pendidikan dan Kebudayaan No 233/C/KR/2015 tentang Penetapan Sekolah Uji Coba Kurikulum 2013 Tahun Pelajaran 2014/2015. Dalam Permendikbud dan surat edaran tersebut dituliskan bahwa bagi sekolah yang pada tahun pelajaran 2014/2015 baru mengimplementasikan kurikulum 2013 selama satu semester, maka pada semester genap ditetapkan untuk kembali menggunakan Kurikulum 2006 (KTSP). Sedangkan untuk sekolah yang pada tahun pelajaran 2014/2015 telah mengimplementasikan Kurikulum 2013 selama tiga semester diharapkan untuk tetap melanjutkan implementasi Kurikulum 2013.

Kemdikbud menegaskan bahwa Kurikulum 2013 tidak dihapus tetapi hanya dihentikan sementara dan akan dilaksanakan secara bertahap. Hal tersebut ditulis dalam pasal 4 Permendikbud Nomor 160 Tahun 2014 yang menyebutkan bahwa satuan pendidikan dasar dan menengah dapat melaksanakan Kurikulum Tahun 2006 paling lama sampai dengan tahun pelajaran 2019/2020. Artinya, pada tahun pelajaran 2020/ 2021 setiap satuan pendidikan dasar dan menengah wajib mengimplementasikan Kurikulum 2013 secara menyeluruh. Kesiapan dari berbagai pihak, terutama guru diperlukan agar penerapan Kurikulum 2013 ini dapat terlaksana dengan baik. Hal tersebut dikarenakan guru adalah salah satu pelaksana teknis di lapangan dalam mengimplementasikan Kurikulum 2013.

Kesiapan adalah tingkat kesediaan atau tingkat persiapan dari keseluruhan kondisi mental, fisik, pengetahuan, ketrampilan dan sikap seseorang atau individu untuk menanggapi dan mempraktekkan suatu kegiatan serta mampu memberikan respon atau jawaban dengan cara tertentu terhadap suatu situasi dan kondisi yang dihadapi (Chaplin, 2006, p.419; Cronbach, 1954, p.74; Slameto, 2003, p.113; Soemanto,
2003, p.191; Dalyono, 2005, p.52). Menurut Rogers (1983, p.163), kesiapan seseorang dalam memutuskan untuk melaksanakan atau tidak melaksanakan sebuah inovasi melalui berbagai tahapan, yaitu pengetahuan, bujukan (sikap), keputusan, implementasi dan konfirmasi (penegasan). Faktor yang mempengaruhi kesiapan guru dalam implementasi Kurikulum 2013 adalah kesiapan pengetahuan, sikap guru, serta kesiapan sarana dan prasarana (Cronbach, 1954, pp.74-75; Soemanto, 2003, pp.191-192; Slameto, 2003, pp.113-115; Ya'acob \& Nor, 2005, p.4; Mulyasa, 2013, p.39).

Kesiapan guru dalam hal pengetahuan, keterampilan, sikap dan minat memainkan peran penting dalam memproduksi dan menciptakan pengajaran yang efektif dan metode pembelajaran (Jusoh, 2012, p.101). Pengajaran yang bagus tergantung pada faktor pengetahuan yang telah dikuasai guru dan kesesuaian metode yang digunakan (Jusoh, 2012, p.99-100). Kesiapan pengetahuan guru dalam implementasi Kurikulum 2013 diperoleh guru salah satunya dengan pelatihan yang diselenggarakan oleh pemerintah. Menurut Heath (2010, p.2), pelatihan kurikulum diharapkan dapat membuat guru lebih siap dalam mengajar di sekolah sesuai yang diharapkan dalam kurikulum dan guru dapat menemukan sumber daya dengan cepat yang mendukung dalam pembelajaran. Selain itu, pelatihan kurikulum diharapkan dapat meningkatkan rasa percaya diri guru dalam mengembangkan kurikulum dan melakukan pembelajaran (Heath, 2010, p.5).

Menurut Kemdikbud (2013, p.3), tujuan dari pelatihan guru salah satunya adalah agar guru mampu melaksanakan tugas sesuai dengan tuntutan kompetensi lulusan, isi, proses pembelajaran dan penilaian kurikulum 2013. Kompetensi inti yang harus dicapai guru setelah mengikuti pelatihan adalah: (1) memiliki sikap yang terbuka untuk menerima Kurikulum 2013, (2) memiliki keinginan yang kuat untuk mengimplementasikan Kurikulum 2013, (3) memiliki pemahaman yang mendalam tentang Kurikulum 2013, (4) memiliki keterampilan menganalisis keterkaitan antara Standar Kompetensi Kelulusan (SKL), Kompetensi Inti (KI), Kompetensi Dasar (KD), Buku Guru, dan Buku Siswa, (4) memiliki keterampilan menyusun Rencana Pelaksanaan Pembelajaran (RPP), (5) memiliki keterampilan mengajar dengan menerapkan pendekatan Scientific, (6) memiliki keterampilan mengajar dengan menerapkan model pembelajaran Problem Based Learning, Project Based 
Learning, dan Discovery Learning, (7) memiliki keterampilan melaksanakan penilaian autentik, (8) memiliki keterampilan berkomunikasi lisan dan tulis dengan runtut, benar, dan santun (Kemdikbud, 2013, p.3). Tujuan dan indikator di atas mengandung arti bahwa guru harus memahami dan menguasai tentang standar kompetensi lulusan, standar isi, standar proses dan standar penilaian. Pengetahuan tentang standar proses di sini termasuk meliputi pendekatan saintifik dan pengetahuan tentang model pembelajaran dalam Kurikulum 2013.

Selain kesiapan pengetahuan, sikap guru juga menjadi salah satu faktor kesiapan guru dalam implementasi Kurikulum 2013. Menurut Sabzian (2013, p.68), sikap siswa dan guru memainkan peranan penting dalam pencapaian tujuan pembelajaran. Sikap adalah respon seseorang terhadap suatu objek yang ditunjukkan melalui tiga aspek, yaitu kognitif (pernyataan/ respon mengenai apa yang dipercaya atau diyakini), afektif (pernyataan/respon menyangkut perasaan), dan konatif (pernyataan/respon yang berkaitan dengan kecenderungan bertindak) (Nitko \& Brookhart, 2007, p.451; Matthews, 2007, p.37; Gable, 1986, p.5; Ebel \& Frisbie, 1986, pp.320-321; Azwar, 2011, pp.23-27; Leder, 1992, p.4, Crano \& Prislin, 2008, p.3). Sikap terbentuk sebagai hasil dari pembelajaran dan pengalaman yang berkembang dalam jangka waktu tertentu (Oruc, 2011, p.83).

Faktor lain yang mempengaruhi kesiapan guru adalah kesiapan sarana dan prasarana. Kesiapan sarana dan prasarana ini adalah milik sekolah tetapi dalam pemanfaatannya digunakan oleh guru secara personal untuk mendukung proses pembelajaran. Oleh karena itu, sarana dan prasarana memegang peranan penting dalam pelaksanaan pembelajaran. Tersedianya berbagai macam fasilitas adalah hal yang terbaik agar dapat terlaksananya berbagai macam kegiatan dan keterbatasan fasilitas akan membatasi aktifitas dalam kegiatan pembelajaran (Beane, 1944, p.163-164). Menurut Mulyasa (2013, p.49), fasilitas dan sumber belajar yang memadai merupakan kunci sukses pelaksanaan kurikulum. Lebih lanjut, Mulyasa (2013: 49) menyatakan fasilitas dan sumber belajar tersebut antara lain laboratorium, pusat sumber belajar dan perpustakaan.

Menurut Orlich et al (2007, p.117), dalam setiap pembelajaran yang dilakukan, penting bagi guru untuk memilih sumber daya pendukung yang tepat untuk membantu siswa dalam mendapatkan pengalaman belajar yang diharap- kan dalam setiap pembelajaran yang dilakukan. Salah satu sarana yang digunakan dalam proses pembelajaran adalah buku teks pelajaran. Menurut Orlich et al. (2007, p.105), buku teks dapat berfungsi untuk menambah wawasan siswa, sebagai media untuk memperbanyak latihan dan dapat juga sebagai alat bantu evaluasi. Selain buku teks, sarana lain yang dapat digunakan misalnya komputer, laboratorium, museum dan situs bersejarah (Orlich et al., 2007, p.106).

Menurut Borich (2007, p.141), menggunakan sarana dalam proses pembelajaran dapat menjadi alat stimulus untuk menyampaikan tujuan pembelajaran. Pemanfaatan teknologi, informasi dan komunikasi juga akan membuat proses pembelajaran berlangsung lebih baik (Beckers \& Voordt, 2003, p.1). Penyediaan laboratorium komputer atau ruang TIK merupakan salah satu aspek yang penting dalam belajar (Beckers \& Voordt, 2003, p.7).

Terkait permasalahan berikut kajian teori yang telah dikemukakan sebelumnya, maka penelitian ini bertujuan untuk mendeskripsikan kesiapan guru matematika SMP di Kabupaten Purworejo dalam implementasi Kurikulum 2013 ditinjau dari pengetahuan guru, sikap guru, dan kesiapan sarana prasarana.

\section{METODE}

Jenis penelitian ini adalah penelitian deskriptif dengan metode penelitian kombinasi (mixed methods) dan menggunakan model Concurrent Embedded Strategy (Campuran Tidak Berimbang). Metode ini mengumpulkan dua macam data (kuantitatif dan kualitatif atau sebaliknya) secara simultan, dalam satu tahap pengumpulan data (Creswell, 2009, p.197). Penelitian ini menggunakan metode kuantitatif sebagai metode primernya, dan dilengkapi metode kualitatif sebagai metode sekunder atau pelengkapnya.

Populasi penelitian ini adalah seluruh guru matematika SMP kelas VII dan kelas VIII di Kabupaten Purworejo, Jawa Tengah. Pengambilan sampel untuk data kuantitatif dalam penelitian ini menggunakan teknik stratified random sampling. SMP di Kabupaten Purworejo dikelompokkan berdasarkan sekolah negeri dan swasta. Baik dari negeri atau swasta masing masing dikelompokkan berdasarkan akreditasi sekolah klasifikasi tinggi (akreditasi A), klasifikasi sedang (akreditasi B) serta klasifikasi rendah (akreditasi C dan belum terakreditasi). Subjek penelitian untuk data kuantitatif adalah 64 orang guru. 
Teknik pengambilan sampel untuk data kualitatif menggunakan purposive sampling. Sampel untuk data kualitatif dalam penelitian ini adalah beberapa orang guru yang diambil dari guru yang dijadikan sampel untuk data kuantitatif. Guru yang diambil untuk dijadikan sampel data kualitatif dengan teknik observasi proses pembelajaran adalah empat orang guru dari sekolah pilot project dan guru yang dijadikan sampel untuk data kualitatif dengan teknik wawancara adalah lima orang guru dari sekolah pilot project.

Teknik pengumpulan data kuantitatif menggunakan angket, dan teknik pengumpulan data kualitatif meggunakan observasi, wawancara dan dokumentasi. Angket yang digunakan terdiri dari angket sikap guru; angket pengetahuan guru yang meliputi pengetahuan tentang standar kompetensi lulusan (SKL), standar isi, standar proses, standar penilaian dan pendekatan saintifik; angket upaya pengembangan diri guru serta angket kesiapan sarana dan prasarana yang mendukung pelaksanaan Kurikulum 2013. Reliabilitas dari instrumen tersebut disajikan pada Tabel 1.

Tabel 1. Estimasi Reliabilitas Instrumen

\begin{tabular}{cc}
\hline Instrumen & $\begin{array}{c}\text { Koefsien } \\
\text { Reliabilitas }\end{array}$ \\
\hline Sikap guru & 0,789 \\
Pengetahuan Guru & 0,728 \\
Upaya Pengembangan Diri & 0,862 \\
Kesiapan Sarana dan Prasarana & 0,729 \\
\hline
\end{tabular}

Teknik analisis data yang digunakan dalam penelitian ini adalah analisis deskriptif kuantitatif dan deskriptif kualitatif. Analisis deskriptif kuantitatif disajikan dalam bentuk tabel yang memuat nilai responden yang sudah dikonversi dalam skala $0-100$. Kesiapan guru matematika ditentukan berdasarkan tingkat kecenderungan dengan melakukan kategorisasi pada variabel. Tingkat kecenderungan dibagi dalam lima kategori tampak pada Tabel 2.

Tabel 2. Kriteria Penilaian

\begin{tabular}{cc}
\hline Instrumen & Kriteria \\
\hline$X>90$ & Sangat Siap \\
$75<X \leq 90$ & Siap \\
$60<X \leq 75$ & Cukup \\
$50<X \leq 60$ & Kurang
\end{tabular}

$X \leq 50$

Sangat Kurang

Kriteria tersebut diadaptasi dari Peraturan Menteri Negara Pendayagunaan Aparatur Negara dan Reformasi Birokrasi Nomor 16 Tahun 2009 tentang Jabatan Fungsional Guru dan Angka Kreditnya. Variabel $X$ merupakan nilai responden yang sudah dikonversi dalam skala 0 - 100. Hasil penelitian kuantitif tersebut kemudian didukung dengan hasil penelitian kualitatif yang diperoleh dari observasi, wawancara dan dokumentasi. Data kualitatif dianalisis dengan model interaktif (imteractive model) yang terdiri dari tiga komponen analisis, yaitu data reduction (reduksi data), data display (penyajian data) dan conclusion drawing and verification (penarikan kesimpulan dan verifikasi) (Miles \& Huberman, 1994, p.10-12).

\section{HASIL DAN PEMBAHASAN}

\section{Hasil Penelitian Kuantitatif}

Hasil penelitian secara kuantitatif memperoleh hasil jumlah skor responden keseluruhan untuk semua komponen adalah 9.046 dengan mean sebesar 141,34. Nilai responden keseluruhan adalah 3.589,71 dengan mean sebesar 56,089. Karena mean nilai responden 56,089; maka berdasarkan Tabel 2, kesiapan guru matematika SMP di Kabupaten Purworejo dalam implementasi Kurikulum 2013 masuk dalam kategori kurang. Secara umum, distribusi frekuensi hasil penelitian ini ditampilkan dalam Tabel 3.

Tabel 3. Kesiapan Guru Matematika SMP di Kabupaten Purworejo dalam Implementasi Kurikulum 2013

\begin{tabular}{cccc}
\hline Kriteria & Nilai & $\begin{array}{c}\text { Jumlah } \\
\text { Guru }\end{array}$ & $\%$ \\
\hline Sangat Siap & $X>90$ & 0 & $0 \%$ \\
Siap & $75<X \leq 90$ & 1 & $1,6 \%$ \\
Cukup & $60<X \leq 75$ & 13 & $20,3 \%$ \\
Kurang & $50<X \leq 60$ & 40 & $62,5 \%$ \\
Sangat Kurang & $X \leq 50$ & 10 & $15,6 \%$ \\
\hline Total & & $\mathbf{6 4}$ & $\mathbf{1 0 0 \%}$ \\
\hline
\end{tabular}

Rangkuman data tersebut didukung oleh data yang diperoleh dari angket dan telaah dokumen RPP. Masing-masing komponen penelitian menyumbangkan rata-rata skor dan nilai yang disajikan pada Tabel 4. 
Pythagoras, 11 (1), Juni 2016 - 82

Susanah Wati, J. Jailani

Tabel 4. Rangkuman Jumlah Skor, Rerata Nilai dan Kriteria Keseluruhan Komponen

\begin{tabular}{lccc}
\hline \multicolumn{1}{c}{ Nama Instrumen } & Jumlah Skor & Rerata Nilai & Kriteria \\
\hline Angket & & & \\
a. Pengetahuan Guru & 1.483 & 57,93 & Kurang \\
b. Upaya Pengembangan Diri & 963 & 20,90 & Sangat Kurang \\
c. Sikap Guru & 3.560 & 69,53 & Cukup \\
d. Kesiapan Sarana dan Prasarana & 799 & 83,23 & Siap \\
Total (Angket) & $\mathbf{6 . 8 0 5}$ & $\mathbf{5 1 , 3 6}$ & Kurang \\
Telaah Dokumen RPP & 2.241 & 77,81 & Baik \\
Total (Angket dan Telaah RPP) & $\mathbf{9 . 0 4 6}$ & $\mathbf{5 6 , 0 9}$ & Kurang \\
\hline
\end{tabular}

Hasil penelitian untuk kesiapan pengetahuan guru matematika SMP di Kabupaten Purworejo masuk dalam kategori sangat kurang. Distribusi frekuensi untuk komponen kesiapan pengetahuan guru disajikan dalam Tabel 5.

Tabel 5. Kesiapan Pengetahuan Guru

Matematika SMP di Kabupaten Purworejo dalam Implementasi Kurikulum 2013

\begin{tabular}{cccc}
\hline Kriteria & Nilai & $\begin{array}{c}\text { Jumlah } \\
\text { Guru }\end{array}$ & $\%$ \\
\hline Sangat Siap & $X>90$ & 0 & $0 \%$ \\
Siap & $75<X \leq 90$ & 0 & $0 \%$ \\
Cukup & $60<X \leq 75$ & 2 & $3,1 \%$ \\
Kurang & $50<X \leq 60$ & 4 & $6,3 \%$ \\
Sangat Kurang & $X \leq 50$ & 58 & $90,6 \%$ \\
\hline Total & & $\mathbf{6 4}$ & $\mathbf{1 0 0 \%}$ \\
\hline
\end{tabular}

Data-data tersebut merupakan rangkuman dari data yang berasal dari pengetahuan tentang standar kompetensi lulusan (SKL), standar isi, standar proses, standar penilaian dan pendekatan saintifik serta upaya pengembangan diri yang dilakukan guru. Rangkuman jumlah skor, rerata nilai, dan kriteria aspek-aspek tersebut disajikan dalam Tabel 6.

Tabel 6. Rangkuman Jumlah Skor, Rerata Nilai, dan Kriteria Kesiapan Pengetahuan Guru Dilihat dari Beberapa Aspek

\begin{tabular}{|c|c|c|c|c|}
\hline No & Aspek & $\begin{array}{l}\text { Jumlah } \\
\text { Skor }\end{array}$ & $\begin{array}{c}\text { Rerata } \\
\text { Nilai }\end{array}$ & Kriteria \\
\hline 1 & SKL & 203 & 63,44 & Cukup \\
\hline 2 & Standar Isi & 142 & 73,96 & Cukup \\
\hline 3 & Standar Proses & 426 & 66,56 & Cukup \\
\hline 4 & Standar Penilaian & 168 & 52,50 & Kurang \\
\hline 5 & Pendekatan Saintifik & 544 & 50,00 & $\begin{array}{l}\text { Sangat } \\
\text { Kurang }\end{array}$ \\
\hline \multirow[t]{2}{*}{6} & $\begin{array}{l}\text { Upaya Pengembang- } \\
\text { an Diri }\end{array}$ & 963 & 20,90 & $\begin{array}{l}\text { Sangat } \\
\text { Kurang }\end{array}$ \\
\hline & Total & 2.446 & 34,12 & $\begin{array}{c}\text { Sangat } \\
\text { Kurang }\end{array}$ \\
\hline
\end{tabular}

Hasil penelitian untuk sikap guru matematika SMP di Kabupaten Purworejo masuk dalam kategori cukup. Distribusi frekuensi untuk komponen sikap guru disajikan Tabel 7.
Tabel 7. Sikap Guru Matematika SMP di Kabupaten Purworejo dalam Implementasi Kurikulum 2013

\begin{tabular}{cccc}
\hline Kriteria & Nilai & $\begin{array}{c}\text { Jumlah } \\
\text { Guru }\end{array}$ & \% \\
\hline Sangat Siap & $X>90$ & 0 & $0 \%$ \\
Siap & $75<X \leq 90$ & 20 & $31,3 \%$ \\
Cukup & $60<X \leq 75$ & 34 & $53,1 \%$ \\
Kurang & $50<X \leq 60$ & 8 & $12,5 \%$ \\
Sangat Kurang & $X \leq 50$ & 2 & $3,1 \%$ \\
\hline Total & & $\mathbf{6 4}$ & $\mathbf{1 0 0 \%}$ \\
\hline
\end{tabular}

Data-data tersebut merupakan rangkuman dari data yang berasal dari aspek kognitif, afektif dan konatif. Rangkuman hasil jumlah skor, rerata nilai, dan kriteria aspek-aspek tersebut disajikan dalam Tabel 8.

Tabel 8. Rangkuman Jumlah Skor, Rerata Nilai, dan Kriteria Sikap Guru Dilihat dari Aspek Kognitif, Afektif dan Konatif

\begin{tabular}{clccc}
\hline No & Aspek & $\begin{array}{c}\text { Jumlah } \\
\text { Skor }\end{array}$ & Rerata Nilai & Kriteria \\
\hline 1 & Kognitif & 1.959 & 76,52 & Siap \\
2 & Afektif & 799 & 62,42 & Cukup \\
3 & Konatif & 802 & 62,66 & Cukup \\
\hline & Total & $\mathbf{3 . 5 6 0}$ & $\mathbf{6 9 , 5 3}$ & Cukup \\
\hline
\end{tabular}

Hasil penelitian untuk kesiapan sarana dan prasarana yang mendukung pelaksanaan Kurikulum 2013 di SMP Kabupaten Purworejo masuk dalam kategori siap. Distribusi frekuensi untuk komponen kesiapan sarana dan prasarana disajikan dalam Tabel 9.

Tabel 9. Kesiapan Sarana dan Prasarana yang Mendukung Pelaksanaan Implementasi Kurikulum 2013 di SMP Kabupaten Purworejo

\begin{tabular}{cccc}
\hline Kriteria & Nilai & $\begin{array}{c}\text { Jumlah } \\
\text { Guru }\end{array}$ & \% \\
\hline Sangat Siap & $X>90$ & 25 & $39,1 \%$ \\
Siap & $75<X \leq 90$ & 20 & $31,3 \%$ \\
Cukup & $60<X \leq 75$ & 10 & $15,6 \%$ \\
Kurang & $50<X \leq 60$ & 7 & $10,9 \%$ \\
Sangat Kurang & $X \leq 50$ & 2 & $3,1 \%$ \\
Total & & $\mathbf{6 4}$ & $\mathbf{1 0 0 \%}$ \\
\hline
\end{tabular}


Data-data tersebut merupakan rangkuman dari data yang berasal dari aspek sarana dan prasarana. Rangkuman hasil jumlah skor, rerata nilai, dan kriteria aspek-aspek tersebut disajikan dalam Tabel 10.

Tabel 10. Rangkuman Jumlah Skor, Rerata

Nilai, dan Kriteria Kesiapan Sarana dan Prasarana

\begin{tabular}{llccc}
\hline No & Aspek & $\begin{array}{c}\text { Jumlah } \\
\text { Skor }\end{array}$ & $\begin{array}{c}\text { Rerata } \\
\text { Nilai }\end{array}$ & Kriteria \\
\hline 1 & Sarana & 681 & 88,67 & Siap \\
2 & Prasarana & 118 & 61,46 & Cukup \\
& Total & $\mathbf{7 9 9}$ & $\mathbf{8 3 , 2 3}$ & Siap \\
\hline
\end{tabular}

\section{Hasil Penelitian Kualitatif}

Dari hasil wawancara diperoleh informasi bahwa upaya pengembangan diri untuk meningkatkan pemahaman guru tentang implementasi Kurikulum 2013 diperoleh dari pelatihan yang diselenggarakan oleh pemerintah selama lima hari berturut-turut. Selebihnya guru mengembangkan diri melalui forum MGMP dan berdiskusi dengan teman sesama guru sekolah pilot project. Dari lima orang responden, hanya seorang guru yang mengaku pernah mencari informasi melalui internet. Pendampingan yang diberikan dari pemerintah adalah pendampingan in-on dan hanya sekali dilakukan. Guru berharap pemerintah melakukan pendampingan dan bimbingan secara intensif kepada guru dalam implementasi Kurikulum 2013.

Sebagian guru mengaku belum mengetahui silabus dan kompetensi dasar untuk kelas IX walaupun kompetensi kelas IX sudah ada dalam Permendikbud Nomor 58 Tahun 2014. Guru mengaku belum mendapatkan gambaran cakupan materi untuk kelas IX. Guru menunggu buku guru dan buku siswa kelas IX terbit untuk mengetahui cakupan materi kelas IX. Padahal sampai menjelang akhir tahun pelajaran 2014/2015, buku guru dan buku siswa tersebut belum didistribusikan ke sekolah.

Dalam pengembangan RPP diperoleh informasi bahwa guru tidak mengembangkan RPP secara mandiri. RPP yang dimiliki adalah RPP hasil dari forum MGMP. RPP yang dimiliki juga tidak menjadi acuan dalam melaksanakan pembelajaran. RPP yang dimilki juga belum lengkap mencakup semua kompetensi dasar.

Dalam penilaian pembelajaran, semua responden mengaku bahwa penilaian dalam Kurikulum 2013 terlalu kompleks sehingga menyita banyak waktu dan tenaga. Pada tahun pelajaran 2014/2015, guru-guru di sekolah pilot project membuat kesepakatan bahwa hanya dua teknik penilaian saja yang dilakukan untuk masing-masing kompetensi, terutama kompetensi sikap. Guru menentukan hasil akhir penilaian dengan menggunakan aplikasi software komputer. Nilai yang diperoleh dimasukkan dalam aplikasi dan langsung memperoleh hasil akhir. Guru mengaku tidak mengetahui secara manual dalam menentukan nilai akhir tersebut.

Guru menilai konsep Kurikulum 2013 bagus, tetapi terlalu terburu-buru diterapkan. Banyak yang harus disiapkan sebelum dilaksanakan secara menyeluruh di Indonesia. Dari lima orang responden, sebanyak tiga responden mengaku tidak nyaman menerapkan Kurikulum 2013 dalam pembelajaran. Responden berharap ada perbaikan dalam Kurikulum 2013 terutama dalam standar penilaian. Teknik penilaian diharapkan lebih sederhana tetapi tetap mengenai sasaran. Guru tidak dibebankan pada proses penilaian yang kompleks serta menyita waktu dan tenaga.

Tiga dari lima responden mengaku belum siap jika diminta menjadi pendamping untuk guru sekolah non pilot project, sedangkan dua responden yang lain menyatakan bersedia jika diberi tugas menjadi pendamping guru sekolah non pilot project. Responden yang belum siap tersebut menyatakan bahwa dari mereka sendiri belum siap untuk melaksanakan Kurikulum 2013 walaupun sudah dua tahun mengimplementasikan Kurikulum 2013.

Informasi yang diperoleh dari wawancara untuk kesiapan sarana dan prasarana adalah bahwa buku guru dan buku siswa untuk semester gasal mengalami keterlambatan dan jumlah buku tidak memenuhi satu buku untuk satu siswa sehingga mengganggu proses pembelajaran. Tetapi pada semester genap, kendala tersebut sudah dapat teratasi. Dari responden diperoleh informasi bahwa materi di dalam buku tersebut masih belum urut. Misal, di dalam buku kelas VII, materi himpunan diberikan sebelum bilangan, padahal di dalam himpunan juga dibahas tentang bilangan. Untuk mengatasi hal tersebut dalam pelaksanaan pembelajaran, guru menyesuaikan sendiri urutan materi yang akan disampaikan kepada siswa. Latihan soal yang terdapat dalam buku siswa juga masih terdapat banyak kesalahan.

Sebagian besar koleksi buku di perpustakaan tentang Kurikulum 2013 adalah buku guru dan buku siswa. Sedangkan untuk buku pendukung lain, guru masih memanfaatkan buku KTSP untuk mendukung proses pembelajaran. 
Sebagian sekolah sudah memilki laboratorium komputer, tetapi laboratorium tersebut hanya digunakan untuk pelajaran TIK kelas IX dan kegiatan ekstrakurikuler. Semua responden mengaku tidak pernah memanfaatkan laboratorium komputer dalam pembelajaran matematika. Salah satu faktor utama guru tidak memanfaatkan laboratorium komputer adalah karena keterbatasan kemampuan di bidang informasi dan teknologi (IT). Selain laboratorium komputer, sebagian sekolah sudah memiliki jaringan internet. Namun demikian, beberapa sekolah tidak memiliki jaringan internet yang memadai sehingga akses internet lambat.

Berdasarkan hasil observasi diperoleh informasi bahwa dari empat orang guru yang diobservasi, hanya seorang guru yang menggunakan pendekatan saintifik dalam pembelajaran di kelas, sedangkan tiga responden lain menggunakan metode konvensional. Tiga responden yang lain tidak menggunakan pendekatan saintifik dengan alasan menyelesaikan materi sebelum ulangan kenaikan kelas. Alasan lain guru tidak meggunakan pendekatan saintifik adalah karena pendekatan saintifik membutuhkan waktu yang lama sehingga guru khawatir materi tidak akan selesai tepat pada waktunya. Selain itu, menurut guru, siswa belum terbiasa menemukan konsep sendiri, sehingga belum sepenuhnya bisa menggunakan pendekatan saintifik. Guru mengaku di awal-awal implementasi Kurikulum 2013 masih bersemangat menggunakan pendekatan saintifik. Tetapi karena beberapa kendala tersebut, penggunaan pendekatan saintifik jarang dilakukan.

RPP yang dimiliki guru tidak selalu menjadi acuan dalam proses pembelajaran. Sebagai contoh, ketika peneliti melakukan observasi di kelas dengan materi bangun ruang, guru tidak menggunakan model pembelajaran projet based learning seperti yang telah direncanakan dalam RPP, tetapi hanya dengan menggunakan demonstrasi melalui slide yang ditampilkan melalui LCD. Begitupun ketika peneliti melakukan observasi pada materi perbandingan senilai dan berbalik nilai. Guru tidak menggunakan model pembelajaran problem based learning dan pendekatan saintifik seperti yang tertulis di RPP tetapi guru menyampaikan dengan metode ceramah.

Teknik dokumentasi dilakukan dengan cara menelaah dokumen RPP dari 64 responden penelitian yang hasilnya telah disampaikan di dalam hasil penelitian kuantitatif. Selain menelaah dokumen RPP, peneliti juga melakukan studi dokumen lebih mandalam. Hasil studi dokumen menunjukkan bahwa RPP yang digunakan adalah RPP hasil dari MGMP dan sebagian guru hanya memperbaiki di bagian identitas sekolah dan identitas diri, sedangkan isi dari RPP masih sama. Selain itu, juga diperoleh informasi bahwa RPP tersebut belum lengkap mencakup semua materi. Misal, kompetensi dasar yang berkaitan dengan materi transformasi geometri belum ada di dalam RPP. Contoh lain adalah, kompetensi dasar yang berkaitan dengan bangun ruang direncanakan untuk 6 kali pertemuan, tetapi RPP yang dibuat hanya 2 kali pertemuan. Oleh karena itu, walaupun hasil telaah dokumen RPP secara kuantitatif masuk kategori baik, tetapi secara kualitatif masuk dalam kategori kurang.

Peneliti juga melakukan cek dokumen yang dimiliki guru. Dari hasil ini diperoleh informasi bahwa hard copy Permendikbud pendukung kurikulum 2013 disimpan oleh kepala sekolah atau wakil kepala sekolah bagian kurikulum. Sebagian guru hanya memilki soft copy dan sebagian yang lain tidak memilki soft copy. Permendikbud yang dimiliki guru adalah Permendikbud yang lama yang diperoleh dari pelatihan atau diklat yang diselenggarakan oleh pemerintah. Sedangkan Permendikbud terbaru, yaitu Permendikbud Nomor 58, 103 dan 104 Tahun 2014 belum dimiliki guru walaupun dalam bentuk soft copy. Bahkan beberapa guru mengaku tidak mengetahui adanya Permendikbud terbaru tersebut.

\section{Pembahasan}

Secara umum kesiapan guru matematika SMP di Kabupaten Purworejo dalam implementasi Kurikulum 2013 masuk dalam kategori kurang. Hasil tersebut didukung oleh komponen kesiapan pengetahuan guru, sikap guru dan kesiapan sarana dan prasarana. Komponen-komponen tersebut akan dibahas lebih rinci sebagai berikut.

Berdasarkan angket yang diberikan kepada responden dapat disimpulkan bahwa kesiapan pengetahuan guru matematika SMP di Kabupaten Purworejo masuk kategori sangat kurang. Kesiapan pengetahuan ini meliputi pengetahuan guru tentang standar kompetensi lulusan (SKL), standar isi, standar proses, standar penilaian dan pendekatan saintifik serta upaya pengembangan yang dilakukan guru. Upaya pengembangan diri guru matematika SMP di Kabupaten Purworejo dalam implementasi Kurikulum 2013 masuk kategori sangat kurang, sedangkan pengetahuan guru masuk kategori kurang. Hal ini sejalan 
dengan hasil penelitian Wibowo \& Wutsqa (2014, p.58) yang menyebutkan bahwa pemahaman guru Matematika SMP di Kota Yogyakarta terhadap KTSP dalam kategori cukup.

Pengetahuan guru tentang standar kompetensi lulusan masuk dalam kategori cukup. Pengetahuan tentang standar kompetensi lulusan ini meliputi kemampuan guru menyebutkan SKL dalam Kurikulum 2013 dan perbedaan atau persamaan SKL Kurikulum 2013 dengan dengan Kurikulum 2006. Sebagian besar guru masih salah dalam menjawab butir yang menyebutkan bahwa kompetensi inti, kompetensi dasar dan indikator pencapaian kompetensi telah disediakan oleh pemerintah dan tertuang dalam Permendikbud. Guru masih belum memahami sepenuhnya jika yang tertuang dalam Permendikbud hanya kompetensi inti dan kompetensi dasar, sedangkan indikator dibuat sendiri oleh guru. Hal ini dikarenakan hampir sebagian besar guru tidak mengembangkan RPP sendiri. RPP yang digunakan guru adalah RPP dari hasil MGMP. Hal ini sejalan dengan hasil penelitian Hifni (2013, p.ii) yang menunjukkan sebanyak $68,75 \%$ guru yang dijadikan subjek penelitian belum menyusun peragkat pembelajaran sendiri

Pengetahuan guru tentang standar isi masuk dalam kategori cukup. Pengetahuan tentang standar isi ini meliputi pengetahuan guru untuk menyebutkan kompetensi dasar dalam Kurikulum 2013 dan perbedaannya dengan Kurikulum 2006. Beberapa guru masih kebingungan untuk butir yang menuliskan tentang kompetensi dasar yang berkaitan dengan kelas IX. Misal, guru mengetahui bahwa kompetensi dasar perbandingan ada di kelas VII dan VIII, tetapi mereka tidak mengetahui apakah kompetensi dasar tersebut ada di kelas IX atau tidak. Sebagian guru memberikan alasan bahwa mereka belum mengetahui materi yang ada di kelas IX karena Kurikulum 2013 baru dilaksanakan sampai kelas VIII. Ketika peneliti menyampaikan bahwa kompetensi dasar dari kelas VII sampai kelas IX sudah tertuang dalam permendikbud, guru mengaku bahwa mereka tidak mencermati permendikbud yang ada. Guru mengaku belum ada gambaran sama sekali untuk materi kelas IX dan belum pernah membaca silabus dari pemerintah.

Pengetahuan guru tentang standar proses masuk dalam kategori cukup. Standar proses ini berkaitan dengan kegiatan guru dalam proses pembelajaran dalam Kurikulum 2013. Walaupun pengetahuan guru tentang standar proses berdasarkan hasil angket masuk dalam kategori cukup, tetapi dalam pelaksanaan proses pembelajaran sebagian besar guru belum melaksanakan proses pembelajaran sesuai yang diharapkan dalam Kurikulum 2013. Temuan ini sejalan dengan hasil penelitian Rusindrayanti \& Santoso (2015), bahwa guru masih mengalami kesulitan dalam melaksanakan pembelajaran dengan langkah 5M (saintifik).

Berdasarkan hasil wawancara dan observasi diperoleh informasi bahwa RPP yang dimiliki guru tidak selalu menjadi acuan dalam proses pembelajaran. Sebagai contoh, ketika peneliti melakukan observasi di kelas dengan materi bangun ruang, guru tidak menggunakan model pembelajaran projet based learning seperti yang telah direncanakan dalam RPP, tetapi hanya dengan menggunakan demonstrasi melalui slide yang ditampilkan melalui LCD. Begitupun ketika peneliti melakukan observasi pada materi perbandingan senilai dan berbalik nilai. Guru tidak menggunakan model pembelajaran problem based learning dan pendekatan saintifik seperti yang tertulis di RPP tetapi guru menyampaikan dengan metode ceramah.

Peneliti melakukan observasi kepada empat orang guru di tiga sekolah yang menjadi pilot project Kurikulum 2013. Hasil rata-rata dari observasi dalam pembelajaran masuk dalam katergori kurang. Dari empat orang guru yang peneliti observasi pembelajarannya, hanya seorang guru yang menggunakan pendekatan saintifik dalam pembelajaran yang membahas materi transformasi geometri. Tetapi ketika peneliti menanyakan RPP, ternyata RPP untuk kompetensi dasar tersebut belum ada dan baru diberikan kepada peneliti beberapa minggu kemudian.

Alasan lain guru tidak menggunakan pendekatan saintifik dalam pembelajaran adalah karena guru mengejar target untuk menyelesaikan materi pembelajaran sebelum ulangan kenaikan kelas tiba. Menurut guru, jika materi tersebut disampaikan dengan menggunakan pendekatan saintifik akan lebih menyita waktu lagi karena pendekatan saintifik membutuhkan waktu yang banyak. Hasil tersebut senada dengan hasil penelitian Mbingo (2006, pp.iv-v) yang menyatakan bahwa guru-guru di Afrika merasa kesulitan dan tidak nyaman menerapkan perubahan kurikulum karena adanya keterbatasan waktu dan biaya.

Berdasarkan hasil wawancara juga diperoleh informasi bahwa menurut guru siswa belum mampu untuk menemukan konsep sendiri seperti yang menjadi tujuan penggunaan pendekatan saintifik. Hal ini sejalan dengan hasil penelitian 
Rulanti (2008, p.ii) yang menyatakan bahwa kendala yang ditemukan pada pelaksanaan KTSP adalah siswa belum siap belajar dengan tuntutan KTSP yang menekankan kepada keaktifan siswa pada proses pembelajaran. Berdasarkan angket, observasi dan wawancara tersebut, peneliti menyimpulkan bahwa pengetahuan guru tentang standar proses masuk dalam kategori cukup, tetapi penerapan pengetahuan guru tersebut dalam proses pembelajaran masuk dalam kategori kurang.

Pengetahuan guru tentang standar penilaian masuk dalam kategori kurang. Hasil tersebut menunjukkan bahwa dalam standar penilaian sebagian besar guru belum memahami sepenuhnya tentang penilaian dalam kurikulum 2013. Hasil tersebut sesuai dengan penelitian Whitelock \& Cross $(2012$, p.8) yang menyatakan bahwa pemahaman guru tentang penilaian autentik masih kurang.

Berdasarkan hasil wawancara, sebagian guru mengaku sangat keberatan dengan penilaian yang ada di dalam Kurikulum 2013. Mereka mengaku bahwa penilaian di dalam Kurikulum 2013 sangat kompleks dan menyita banyak waktu. Guru berharap bahwa penilaian dalam Kurikulum 2013 dibuat lebih sederhana tetapi tetap mengenai sasaran. Guru di sekolah pilot project membuat kesepakatan untuk melaksanakan dua teknik penilaian saja terutama untuk penilaian tentang sikap. Hal ini diharapkan dapat mengurangi beban guru dalam penilaian.

Berdasarkan hasil wawancara juga diperoleh bahwa untuk menentukan penilaian akhir, guru menggunakan aplikasi dari pemerintah. Guru tinggal memasukkan nilai-nilai yang diperoleh dan hasil akhirnya secara otomatis akan keluar dalam aplikasi tersebut. Hal ini membuat guru tidak pernah mencermati bagaimana proses penentuan hasil akhir secara manual. Hasil penelitian ini sejalan dengan hasil penelitian Mulabbiah (2006, p.ii) tentang implementasi KBK yang menunjukkan bahwa dalam pelaksanaan kegiatan penilaian dan pelaksanaan remidi serta pengayaan yang dilakukan guru masih kurang baik.

Pengetahuan tentang standar proses juga berkaitan dengan pengetahuan guru tentang pendekatan saintifik. Pengetahuan guru tentang pendekatan saintifik masuk dalam kategori sangat kurang. Berdasarkan hasil angket diperoleh informasi bahwa sebagian besar guru mengalami kebingungan dengan kegiatan mangamati. Hasil penelitian menunjukkan bahwa guru meminta siswa mengamati soal pada halaman tertentu masuk dalam kategori mengamati. Kegiatan mengamati adalah kegiatan mengamati fenomena, dapat dengan mengamati gambar, membaca cerita, atau mengamati contoh-contoh.

Hasil penelitian juga menunjukkan bahwa ketika guru meminta siswa mengamati, guru juga mengajukan pertanyaan kepada siswa. Misal, guru menyajikan beberapa contoh barisan dan bukan barisan. Guru meminta siswa mengamati contoh barisan dan bukan barisan kemudian meminta siswa menemukan perbedaan barisan dan bukan barisan merupakan kegiatan mengamati menurut sebagian guru. Kegiatan mengamati seharusnya hanya sampai meminta siswa mengamati contoh barisan dan bukan barisan. Sedangkan pertanyaan tentang apakah perbedaan barisan dan bukan barisan adalah contoh pertanyaan yang diharapkan muncul dari siswa dalam kegiatan menanya.

Setelah kegiatan mengamati dilanjutkan dengan kegiatan menanya. Hasil penelitian menunjukkan bahwa lebih dari 50\% guru berpendapat bahwa guru mengajukan pertanyaan kepada siswa termasuk dalam kegiatan menanya. Kegiatan menanya adalah kegiatan siswa mengajukan pertanyaan dari hasil mereka mengamati. Jadi di dalam kegiatan menanya ini, yang mengajukan pertanyaan adalah siswa. Jika tidak ada pertanyaan dari siswa, guru dapat membantu dengan memberikan pancingan agar siswa bertanya. Kegiatan menanya diharapkan dapat meningkatkan keaktifan dan ketrampilan serta kreatifitas siswa dalam pembelajaran. Menurut Rasiman \& Agnita (2014, p.536), kegiatan menanya dalam proses pembelajaran bertujuan untuk mengembangkan kreativitas, rasa ingin tahu, keterampilan untuk merumuskan pertanyaan agar membentuk pemikiran yang kritis.

Berdasarkan hasil angket yang diisi oleh responden menunjukkan bahwa upaya pengembangan diri yang dilakukan oleh guru masuk dalam kategori sangat kurang. Berdasarkan hasil wawancara, diperoleh informasi bahwa sebagian besar guru mendapatkan informasi hanya ketika mengikuti sosialisai dan pelatihan selama 5 hari yang diselenggarakan oleh pemerintah. Selebihnya mereka hanya mendapatkan informasi melalui MGMP. Guru mengaku jarang mencari informasi yang berkaitan dengan Kurikulum 2013 melalui internet, artikel atau jurnal.

Berdasarkan hasil wawancara juga diperoleh informasi pemerintah tidak melakukan pendampingan secara intensif di sekolah pilot project. Pendampingan hanya dilakukan sekali yaitu ketika kegiatan in-on. Guru berharap 
pemerintah mengadakan sosialisasi dan pendampingan secara berkesinambungan agar guru mempunyai wadah untuk mengikuti perkembangan informasi tentang Kurikulum 2013.

Aspek kognitif guru masuk dalam kategori siap. Aspek kognitif meliputi pernyataan atau respon mengenai apa yang dipercaya atau diyakini. Guru memiliki keyakinan dan penilaian bahwa Kurikulum 2013 baik untuk diterapkan dalam pembelajaran. Hal ini didukung dengan hasil wawancara dengan beberapa guru yang berpendapat bahwa konsep yang ada dalam Kurikulum 2013 bagus karena mendorong siswa untuk aktif dalam pembelajaran. Para guru mendukung penerapan Kurikulum 2013, hanya saja guru berharap Kurikulum 2013 disiapkan secara matang dan utuh terlebih dahulu sebelum diterapkan.

Sikap guru ditinjau dari aspek afektif masuk dalam kategori cukup. Aspek afektif meliputi perasaan senang dan nyaman dalam mengimplementasikan Kurikulum 2013. Menurut hasil wawancara sebagian guru menganggap bahwa Kurikulum 2013 belum siap untuk diterapkan. Penerapan Kurikulum 2013 seharusnya dilakukan secara bertahap dan tidak terburuburu. Bahan ajar dalam kurikulum seharusnya diberikan semua mulai dari kelas VII sampai kelas IX sehingga guru mendapatkan gambaran tentang batasan materi di setiap jenjang kelas.

Berdasarkan hasil wawancara diperoleh informasi bahwa tiga orang guru merasa belum siap dalam mengimplementasikan Kurikulum 2013. Menurut guru, terlalu kompleksnya penilaian dalam Kurikulum 2013 menyita banyak waktu dan tenaga. Guru berharap apabila Kurikulum 2013 akan tetap dilaksanakan, maka ada perbaikan dalam sistem penilaian sehingga sistem penilaian menjadi lebih sederhana dan tetap sesuai sasaran. Hasil penelitian tersebut senada dengan hasil penelitian Othman, Salleh dan Norani (2013, p.1) yang menyebutkan bahwa guru memiliki perspektif negatif terhadap kecukupan waktu untuk melaksanakan standar penilaian SBA dalam pelaksanaan kurikulum di Malaysia.

Sikap guru ditinjau dari aspek konatif masuk dalam kategori cukup. Aspek konatif meliputi kesediaan guru matematika melaksanakan Kurikulum 2103. Tiga dari responden menyatakan tidak siap jika diminta menjadi pendamping untuk sekolah non pilot project walaupun mereka sudah dua tahun melaksanakan Kurikulum 2013. Menurut guru, pendekatan saintifik sulit untuk diterapkan di kelas. Siswa belum terbiasa untuk mengamati, menanya, mengumpulkan informasi, menganalisis data dan mengkomunikasikan sesuai harapan guru. Siswa masih cenderung pasif dan pembelajaran menjadi tidak efektif serta menyita banyak waktu hanya untuk satu sub pokok bahasan.

Secara umum, kesiapan guru matematika SMP di Kabupaten Purworejo dalam implementasi Kurikulum 2013 ditinjau dari sikap guru masuk dalam kategori cukup. Hasil penelitian ini sejalan dengan hasil penelitian Mackinlay (2014, p.2) yang menyatakan bahwa guru cenderung memberikan tanggapan secara negatif terhadap perubahan kurikulum dan membutuhkan waktu 18 bulan untuk mengubah tanggapan/ perspektif negatif guru terhadap perubahan kurikulum.

Aspek sarana meliputi ketersediaan buku guru dan buku siswa yang memadai, dokumen pendukung implementasi Kurikulum 2013, KTSP, silabus, RPP dan media pembelajajaran. Berdasarkan hasil angket, kesiapan sarana masuk dalam kategori siap. Berdasarkan hasil observasi dan wawancara diperoleh informasi bahwa buku siswa pada awal semester gasal mengalami keterlambatan sehingga berpengaruh dalam proses pembelajaran.

Berdasarkan hasil angket diperoleh informasi bahwa hampir semua sekolah sudah memiliki Permendikbud pendukung implementasi Kurikulum 2013. Tetapi berdasarkan hasil wawancara dan observasi, Permendikbud tersebut tidak disimpan oleh guru, tetapi dicetak dan disimpan wakil kepala sekolah bagian kurikulum. Sebagian guru hanya memiliki softcoy Permendikbud tersebut, dan hampir semua guru mengaku tidak mencermati isi Permendikbud tersebut, bahkan ada yang belum pernah membaca sama sekali. Contohnya, hasil angket menunjukkan sebanyak $86 \%$ sekolah memiliki dokumen Permendikbud Nomor 58 Tahun 2014, tetapi mereka mengaku belum mengetahui bahwa dalam lampiran permendikbud tersebut terdapat silabus dari pemerintah. Akibatnya, guru mengaku belum mendapat gambaran tentang cakupan materi untuk kelas IX. Hasil tersebut menunjukkan pentingnya guru mengetahui dan memahami pedoman dalam pelaksanaan Kurikulum 2013.

Aspek prasarana meliputi ketersediaan perpustakaan yang memiliki buku pendukung Kurikulum 2013 yang memadai, laboratorium komputer yang aktif digunakan dengan software yang mendukung, dan jaringan internet yang memadai. Kesiapan prasarana yang masih 
kurang di beberapa sekolah adalah tersedianya laboratoium komputer yang aktif digunakan dengan software yang mendukung. Berdasarkan hasil wawancara, guru jarang menggunakan laboratorium komputer dalam pembelajaran matematika. Laboratorium komputer hanya digunakan untuk kegiatan ekstrakurikuler komputer. Kegiatan pembelajaran matematika di kelas hanya menggunakan laptop guru dan LCD. Sebagian guru mengaku tidak mahir di bidang informasi dan teknologi (IT) sehingga tidak menggunakan laboratorium komputer untuk praktik dalam pembelajaran matematika. Hasil penelitian ini senada dengan hasil penelitian Buabeang \& Andoh (2012, p.136) yang menyatakan bahwa sebagian besar guru tidak menggunakan IT dalam pembelajaran dikarenakan keterbatasan pengetahuan guru tentang IT.

Pemerintah perlu memfasilitasi pelatihan tentang IT agar meningkatkan ketrampilan guru di bidang IT. Menurut Buabeang \& Andoh (2012, p.147), pada tingkat sekolah, faktorfaktor seperti dukungan, pendanaan, pelatihan dan fasilitas mempengaruhi guru untuk mengadopsi dan mengintegrasikan teknologi dalam proses pembelajaran di kelas. Lebih lanjut Buabeang \& Andoh (2012, p.147) menyatakan bahwa guru professional merupakan faktor kunci untuk keberhasilan integrasi komputer dalam proses pembelajaran di kelas.

\section{SIMPULAN DAN SARAN}

Berdasarkan hasil penelitian dan pembahasan tersebut, maka dapat disimpulkan bahwa kesiapan guru matematika SMP di Kabupaten Purworejo dalam implementasi Kurikulum 2013 masuk dalam kategori kurang. Kesiapan tersebut dilihat dari kesiapan pengetahuan guru tentang implementasi Kurikulum 2013 yang masuk kategori sangat kurang, sikap guru terhadap implementasi Kurikulum 2013 yang masuk kategori cukup serta kesiapan sarana dan prasarana yang mendukung pelaksanaan Kurikulum 2013 yang masuk kategori siap.

Berdasarkan kesimpulan tersebut, maka disarankan beberapa hal berikut: (1) untuk pemerintah pusat, dalam hal ini Kementerian Pendidikan dan Kebudayaan diharapkan untuk mengevaluasi kembali kebijakan tentang Kurikulum 2013 dengan mengadakan perbaikan Kurikulum 2013; (2) Kurikulum 2013 dilaksanakan secara bertahap baik tingkat sekolah maupun tingkat jenjang pendidikan kemudian dievaluasi pelaksanaannya secara berkesinambungan untuk menetapkan kebijakan selanjut- nya; (3) Bagi PPPPTK Matematika dan LPMP Jawa Tengah, diharapkan mengadakan pelatihan dan diklat yang lebih intensif untuk meningkatkan pemahaman guru tentang Kurikulum 2013;(4) bagi Dinas Pendidikan, Pemuda dan Olahraga Provinsi Jawa Tengah dan Dinas Pendidikan, Pemuda dan Olahraga Kabupaten Purworejo agar terus melakukan pendampingan dan monitoring kepada guru dalam mengimplementasikan Kurikulum 2013; (5) bagi pihak sekolah diharapkan untuk memotivasi, memfasilitasi dan menugaskan guru untuk mengembangkan diri dalam rangka meningkatkan kualitas pembelajaran dengan memberikan rekomendasi untuk mengikuti kegiatan yang relevan serta menyediakan sarana dan prasarana yang mendukung dalam pembelajaran matematika menggunakan Kurikulum 2013; (6) untuk guru matematika SMP di Kabupaten Purworejo diharapkan untuk terus melakukan upaya pengembangan diri dalam rangka meningkatkan pemahaman tentang Kurikulum 2013 baik secara mandiri atau bersama-sama; dan (7) guru secara konsisten memotivasi diri untuk melaksanakan pembelajaran sesuai dengan Kurikulum 2013.

\section{DAFTAR PUSTAKA}

Azwar, S. (2011). Sikap manusia teori dan pengukurannya. Yogyakarta: Pustaka Pelajar.

Beane, J. A., Toepfer, C. F. \& Alessi, S. J. (1944). Curriculum planning and development. Newton, MA: Allyn and Bacon, Inc.

Beckers, R. \& Voordt, T. (2013). Facilitating new ways of learning in Dutch higher education. $12^{\text {th }}$ EuroFM Research Symposium.

Borich, G. D. (2007). Effective teaching methods $\left(6^{\text {th }} e d\right)$. Upper Saddle River, NJ: Pearson Merril Prentice Hall.

Buabeang, C. \& Andoh. (2012). Factors influencing teachers' adoption and integration of information and communication technology into teaching: A review of the literature. International Journal of Education and Development using Information and Communication Technology (IJEDICT), 8(1), 136-155.

Chaplin, J. P. (2011). Kamus lengkap psikologi (terjemahan Kartini Kartono). Jakarta: Raja Grafindo Persada. (Buku asli diterbitkan tahun 1981). 
Creswell, J. D. (2009). Research design qualitative, quantitative and mixed methods approaches. Thousand Oaks, CA: Sage Publications Ltd.

Crano, W. D., \& Prislin, R. (2008). Attitudes and attitude change. New York, NY: Taylor \& Francis Group, LLC.

Cronbach, L. J. (1954). Psychology. New York, NY: Harcourt, Brace and Company, Inc.

Dalyono. (2005). Psikologi pendidikan. Jakarta: Rineka Cipta.

Ebel, R. I. \& Frisbie, D. A. (1986). Essentials of educational measurement $\left(4^{\text {th }} \mathrm{ed}\right)$. Englewood Cliffs, NJ: Prenctice-Hall, Inc.

Finch C.R \& Crunkilton J.R. (1979). Curriculum development in vocational and technical education planning, content and implementation. Needham Heights, MA: Allyn and Bacon, Inc.

Gable, R. K. (1986). Instrument development in the affective domain. Hingham, MA: Kluwer-Nijhoff Publishing.

Heath, R. R. (2010). Ensuring preservice teachers' radiness to teach standardsbased curricula. North Carolina Middle School Association Journal, 25(2), 1-9.

Howell, K. W. \& Nolet V. (2000). Curriculum based evaluation: Teaching and decision making $\left(3^{\text {rd }} \quad e d\right)$. Belmont, CA: Wadsworth Thomson Learning.

Rulanti, I. Y. W. (2008). Kesiapan guru matematika SMK jurusan bisnis manajemen dalam melaksanakan KTSP di Kabupaten Magetan. Tesis magister, tidak diterbitkan, Universitas Sebelas Maret, Surakarta.

Jackman., H. L. (2001). Early education curriculum: a child connection to the world $\left(2^{\text {nd }} e d\right.$.). Albany, NY: Library of Congress Cataloging-in-Publication Data.

Jusoh, R. (2012). Effect of teachers' readiness in teaching and learning of interpreunership education in primary schools. International Interdisciplinary Journal of Education, 1(7), 98-102.

Kemdikbud. (2013). Materi pelatihan guru implmentasi kurikulum 2013 SMP/MTs Matematika. Jakarta: Kemdikbud.
Kemdikbud. (2014). Materi pelatihan guru implementasi kurikulum 2013 tahun 2014. Jakarta: Kemdikbud.

Leder, G. (1992). Attidudes to mathematics. Mathematics Education Research Journal, 4(3), 1-7.

Mackinlay, M. (2014). Teachers' response to curriculum reforms: Primary. Diambil pada tanggal 9 September 2014, dari http://www.schoolzone.co.uk/schools/NC res/Primary/Curriculum_reform_report_P rimary_updated.pdf.

Matthews, R. J. (2007). The measure of mind: propositional attitudes and their attribution. Oxford, UK: Oxford University Press Inc.

Mbingo, S. J. (2006). An investigation into the implementation of the new curriculum by foundation phase teachers in Bethal Mpulanga. Mini Dissertation [versi elektronik]. Diakses pada tanggal 9 September 2014 https://ujdigispace.uj.ac.za/bitstream/hand le/10210/565/MBINGO.pdf? sequence=1.

Kemendikbud. (2013). Surat Edaran Menteri Pendidikan dan Kebudayaan Nomor: 156928/MPKA/KR/2013 tentang Implementasi Kurikulum 2013. Jakarta: Kemendikbud.

Kemendikbud. (2014). Peraturan Menteri Pendidikan dan Kebudayaan Nomor 160 Tahun 2014 tentang Pemberlakukan Kurikulum Tahun 2006 dan Kurikulum 2013. Jakarta: Kemendikbud.

Mendikbud. (2015). Surat Edaran Menteri Pendidikan dan Kebudayaan Nomor: 233/C/KR/2015 tentang Penetapan Sekolah Uji Coba Kurikulum 2013 Tahun Pelajaran 2014/2015. Jakarta: Kemendikbud.

Mennegpan. (2009). Peraturan Menteri Negara Pendayagunaan Aparatur Negara dan Reformasi Nomor 16 Tahun 2009 tentang Jabatan Fungsional Guru dan Angka Kreditnya. Jakarta: Kemendikbud.

Miles, M. B., \& Huberman, A.M. (1994). Qualitative data analysis. Thousand Oaks, CA: Sage Publications.

Hifni, M. (2013). Implementasi kurikulum tingkat satuan pendidikan (KTSP) pada 
mata pelajaran matematika di Madrasah Aliyah NW, Kecamatan Suralaga, Lombok Timur, NTB. Tesis magister, tidak diterbitkan, Universitas Negeri Yogyakarta, Yogyakarta.

Mulabbiah. (2006). Evaluasi pelaksanaan KBK di SMAN di Kabupaten Lombok Timur. Tesis magister, tidak diterbitkan, Universitas Negeri Yogyakarta, Yogyakarta.

Mulyasa, E. (2007). Menjadi guru professional: Menciptakan pembelajaran kreatif dan menyenangkan. Bandung: Remaja Rosdakarya.

Mulyasa, E. (2013). Pengembangan dan implementasi kurikulum 2013. Bandung: PT Remaja Rossdakarya.

NCTM. (2000). Principles and standarts for school mathematics. Reston, VA: The National Council of Teachers of Mathematics, Inc.

Nitko, A. J., \& Brookhart, S. M. (2007). Educational assessment of students. Upper Saddle River, NJ: Pearson Merrill Prentice Hall.

Olivia, P. F. (1992). Developing the curriculum. New York, NY: Harper Collins Publisher.

Orlich, D.C, Harder, R. J., Callahan, R. C., et al. (2007). Teaching strategies. New York, NY: Houghton Miffin Campany.

Oruc, N. (2011). The perception of teaching as a profession by turkish trainer teachers: attitudes towards being a teacher. International Journal of Humanities and Social Science, 1(4), 83-87.

Othman, I., Salleh, N. M., \& Norani, N. A. M. (2013). The implementation of school based assessment in primary school standard curriculum. International Journal of Education and Research. 1(7), $1-10$.

Rasiman., Pramasdyahsari., \& Agnita Siska. (2014). Development of mathematics learning media e-comic based on flip book maker to increase the critical thinking skill and character of junior high school students. International Journal of Education and Research, 2(11), 535-544.

Rogers, E. M. (1983). Diffusion of innovations. New York, NY: The Free Press.

Rusindrayanti, R., \& Santoso, R. (2015). Implementasi pendekatan saintifik mapel matematika kelas VII tahun pelajaran 2013/2014 pada kurikulum 2013 DIY. PYTHAGORAS: Jurnal Pendidikan Matematika, $\quad$ 10(1), 80-94. doi:http://dx.doi.org/10.21831/pg.v10i1.9 112

Sabzian, F., \& Gilakjani, A. B. (2013). Teacher's attitudes about computer technology training, professional development integration, experience, anxiety, and literacy in English language teaching and learning. Internatioan Journal of Applied Science and Technology, 3(1), 67-75.

Slameto. (2003). Belajar dan faktor-faktor yang mempengaruhi. Jakarta: Rineka Cipta.

Soemanto, W. (2003). Psikologi pendidikan. Jakarta: PT Rineka Cipta.

Whitelock, D, \& Cross, S. (2012). Authentic assessment: what does it mean and how is it instantied by a group of distance learning academics? International Journal of e-Assessment, 2(1), 1-10

Wibowo, R., \& Wutsqa, D. (2014). evaluasi pelaksanaan kurikulum tingkat satuan pendidikan (ktsp) mata pelajaran matematika SMP di Kota Yogyakarta. Jurnal Riset Pendidikan Matematika, 1(1), 58-68. doi:http://dx.doi.org/10.21831/jrpm.v1i1 . 2664

Ya'acob, A. \& Nor, N. F. M. (2005). Implementation of Malaysian smart school: an investigation of teachinglearning practices and teacher-student readiness. Internet Journal of e-Language Learning \& Teaching, 2(2), 16-25. 